Article

\title{
Impact of a Ration Negative in Dietary Cation-Anion Difference and Varying Calcium Supply Fed before Calving on Colostrum Quality of the Dams and Health Status and Growth Performance of the Calves
}

\author{
Abbas Rajaeerad ${ }^{1} \mathbb{D}$, Gholam Reza Ghorbani ${ }^{1}$, Mohammad Khorvash ${ }^{1}$, \\ Ali Sadeghi-Sefidmazgi ${ }^{1}$, Amir Hossein Mahdavi ${ }^{1}$, Saman Rashidi ${ }^{1}$, \\ Mirja Rosmarie Wilkens ${ }^{2, *(\mathbb{D})}$ and Martin Hünerberg ${ }^{3}$ \\ 1 Department of Animal Sciences, College of Agriculture, Isfahan University of Technology, \\ Isfahan 84156-83111, Iran; a.rajaeerad@ag.iut.ac.ir (A.R.); ghorbani@cc.iut.ac.ir (G.R.G.); \\ khorvash@cc.iut.ac.ir (M.K.); sadeghism@cc.iut.ac.ir (A.S.-S.); mahdavi@cc.iut.ac.ir (A.H.M.); \\ saman.rashidi@alumni.iut.ac.ir (S.R.) \\ 2 Department of Animal Sciences, Animal Nutrition Physiology, University of Goettingen, Kellnerweg 6, \\ 37077 Goettingen, Germany \\ 3 Department of Animal Sciences, Ruminat Nutrition Unit, University of Goettingen, Kellnerweg 6, \\ 37077 Goettingen, Germany; martin.huenerberg@uni-goettingen.de \\ * Correspondence: mirja.wilkens@uni-goettingen.de; Tel.: +49-551-39-23335
}

Received: 6 August 2020; Accepted: 17 August 2020; Published: 20 August 2020

Simple Summary: We fed diets with low and high levels of calcium or a negative dietary cation-anion difference (DCAD) to dairy cows before calving and compared their colostrum quality and the health and growth performance of their calves. There were no differences in birth weight and colostrum quantity and composition among groups. However, calves born to cows fed a diet with a negative DCAD had lower body weight and higher prevalence for diarrhea before weaning. The level of Ca in the diet of the dams before calving had no impact on the body weight, feed intake, and health of the calves.

\begin{abstract}
This study investigated the effect of diets negative in dietary cation-anion difference (DCAD) or restricted in Ca fed prepartum to dairy cows for three weeks on colostrum yield and composition, and the health and growth performance of their calves. Thirty-six pregnant non-lactating Holstein-Friesian cows were randomly assigned to three isoenergetic diets: (1) low Ca: $0.24 \% \mathrm{Ca}$, DCAD: $+86 \mathrm{mEq} / \mathrm{kg}$; (2) high Ca: $1.23 \% \mathrm{Ca}$, DCAD: $+95 \mathrm{mEq} / \mathrm{kg}$; and (3) low DCAD: $1.28 \% \mathrm{Ca}$, DCAD: $-115 \mathrm{mEq} / \mathrm{kg}$ (all dry matter (DM) basis). While colostrum quality was not affected, low Ca supply prepartum tended to increase the colostrum yield compared to high $\mathrm{Ca}$ (low $\mathrm{Ca}=8.81 \mathrm{vs}$. high $\mathrm{Ca}=5.39 \mathrm{~kg}$ ). However, calves from cows fed low DCAD showed higher serum concentrations of $\mathrm{K}$, lower body weight (BW), starter feed intake and average daily weight gain before weaning compared to low Ca and high Ca calves (53.12 vs. 57.68 and $57.32 \mathrm{~kg}$ ) but BW was similar postweaning (d 70). In addition, calves from dams fed low DCAD were more likely to develop diarrhea and had increased number of days with abnormal fecal scores. Consequently, calves from low DCAD dams had to be treated more frequently.
\end{abstract}

Keywords: prepartum dairy cows; dietary cation-anion difference; Ca restriction; colostrum; neonate calves; body weight development 


\section{Introduction}

Supplementing dairy cows with anionic salts during the last three weeks before calving (i.e., close-up period) improves Ca homeostasis, decreases the risk of retained placenta, metritis, and enhances the overall health status during the early postpartum phase [1,2]. The adverse effect of a negative dietary cation-anion difference (DCAD) on prepartum feed intake is also well documented [1-3]. Compromised dry matter intake (DMI) during late gestation is frequently associated with decreased colostrum production and reduced fetal growth [4-6]. However, findings whether a small or moderate decrease in DMI (5-15\%) in close-up cows fed low-DCAD diets could affect colostrum production or fetal growth are limited and inconsistent [2,3].

For example, reducing the DCAD from -70 to $-180 \mathrm{mEq} / \mathrm{kg}$ diet dry matter (DM) decreased colostrum yield by $1.4 \mathrm{~kg}$ but had no effect on the birth weight of calves [7]; whereas increasing the duration during which the low DCAD diets were fed from 21 to $42 \mathrm{~d}$ prepartum, decreased the birth weight by $2.8 \mathrm{~kg}$ [8]. In contrast, feeding a low DCAD diet containing $-157.9 \mathrm{mEq} / \mathrm{kg}$ DM did not affect prepartum DMI, fetal growth, and colostrum yield compared to the control (+188.5 mEq/kg DM [9]).

Calves from hypocalcemic cows have a greater risk of developing diarrhea and respiratory infections compared to calves born from non-hypocalcemic dams [10,11]. Based on these findings, it could be speculated that improving Ca homeostasis in dairy cows around calving by lowering their DCAD during the close-up phase might have a positive impact on the health of calves.

Feeding diets formulated to have a negative DCAD induces a compensated metabolic acidosis, which can lead to decreased blood and urine $\mathrm{pH}$ and altered the blood gas concentrations [3,12]. Even relatively small changes of the maternal acid-base balance may cause fetal distress in humans, which can affect the function of the fetal central nervous and cardiovascular system [13]. The placental nutrient transfer system of cows is highly vascularized, particularly during the last trimester [14]. Therefore, it is possible that a maternal metabolic acidosis could affect the development of the calf in utero and compromise its neonatal health and growth performance. Respiratory acidosis by prolonged or intermittent asphyxia in utero has been associated with reduced efficiency of colostral Ig absorption and increased mortality [15-17]. On the other hand, a manipulation of dietary mineral supplementation during the prepartum period has been shown to increase blood immunoglobulin A (IgA) and IgM in the cows, their colostrum and their newborn calves [18].

Several studies reported that the absorption of IgG in neonatal calves was negatively affected by prepartum exposure of their dams to low-DCAD diets [19-22]. In contrast, feeding two levels of negative DCAD ( -70 or $-180 \mathrm{mEq} / \mathrm{kg} \mathrm{DM}$ ) and for 21 or $42 \mathrm{~d}$ prepartum did not lead to changes in the efficiency of IgG transfer between treatments [8]. However, feeding cows with diets containing -70 or $-180 \mathrm{mEq} / \mathrm{kg} \mathrm{DM}$ for $42 \mathrm{~d}$ induced a transient metabolic acidosis in their calves and decreased their BW at birth and day 62 compared to feeding for only 21 days prepartum [8].

Recently, our group found that restricting the Ca level in the diet of prepartum cows to $0.24 \%$, together with a reduction of $\mathrm{K}(1.14 \%$; both DM basis), is an effective means to reduce the occurrence of periparturient hypocalcemia [23]. However, feeding a low DCAD diet $(-115 \mathrm{mEq} / \mathrm{kg} \mathrm{DM})$ decreased milk protein content during the first $21 \mathrm{~d}$ of lactation, which may have a negative impact on the colostrum quality.

To our knowledge, there is no research examining the effect of a prepartum Ca restriction of dairy cows on colostrum yield and composition, and the physiology of their calves. Therefore, the objectives of this experiment were to determine if feeding low DCAD diets during the prepartum period affects the colostrum quality and quantity of the dams or blood metabolites, health and performance of the calves, and to determine whether a Ca restriction of close-up cows has any advantageous effects on colostrum quality and health and growth performance of their calves in comparison low DCAD close-up diets. 


\section{Materials and Methods}

The study was conducted from March 2017 to September 2017 at the Lavark Research Station of Isfahan University of Technology (IUT; Isfahan, Iran). Before the start of the study, the experimental protocol was reviewed and approved by the IUT institutional animal care committee. Cows and calves were cared for in accordance with the guidelines of the Iranian Council of Animal Care.

\subsection{Experimental Design and Treatment Diets}

Thirty-six non-lactating multiparous Holstein-Friesian cows were moved into individual sand-bedded pens 21 days before their expected calving date. The cows were assigned to 3 dietary treatments based on their previous 305-d milk yield, BW, body condition score (BCS), and parity. Treatments were: (1) low Ca: $0.24 \% \mathrm{Ca}, 1.14 \% \mathrm{~K}$, and DCAD: $+86 \mathrm{mEq} / \mathrm{kg} \mathrm{DM}$; (2) high Ca: $1.23 \% \mathrm{Ca}$, 1.17\% K, and DCAD: $+95 \mathrm{mEq} / \mathrm{kg} \mathrm{DM}$; and (3) low DCAD = high Ca diet supplemented with 5.51\% SoyChlor (Mehre-Bistun Corporation, Tehran, Iran) 1.28\% Ca, 1.16\% K, and DCAD: $-115 \mathrm{mEq} / \mathrm{kg}$ $\mathrm{DM}$ (all diet DM basis). Diets were formulated to meet the nutrient requirements of prepartum dairy cows using the Cornell Net Carbohydrate and Protein System (CNCPS Version 5.1, Cornell University, Ithaca, NY, USA) and to be isonitrogenous and isoenergetic (Table 1). Cows were fed once per day for an ad libitum intake. Further details concerning the management of the cows are described by Rajaeerad et al. [24].

Table 1. Ingredient and chemical composition of the prepartum diets and calf starter.

\begin{tabular}{|c|c|c|c|c|}
\hline \multirow{2}{*}{ Item } & \multicolumn{3}{|c|}{ Prepartum Diet ${ }^{1}$} & \multirow{2}{*}{ Calf Starter } \\
\hline & Low Ca & High Ca & Low DCAD & \\
\hline \multicolumn{5}{|l|}{ Ingredient, $\%$ of DM } \\
\hline Corn silage & 34.96 & 34.49 & 34.58 & 0 \\
\hline Wheat straw, chopped & 16.84 & 15.36 & 16.33 & 0 \\
\hline Alfalfa hay & 0 & 0 & 0 & 10.0 \\
\hline Barley grain, ground & 8.35 & 5.92 & 5.49 & 7.3 \\
\hline Corn, ground & 17.22 & 19.2 & 18.52 & 56.2 \\
\hline Soybean meal & 7.56 & 10.0 & 0 & 23.2 \\
\hline Canola meal & 12.6 & 10.20 & 14.68 & 0 \\
\hline Palm fat & 0.46 & 0.46 & 0.95 & 0 \\
\hline Mineral supplement ${ }^{2}$ & 0.76 & 0.76 & 0.76 & 0.4 \\
\hline Vitamin supplement ${ }^{3}$ & 0.76 & 0.76 & 0.76 & 0.4 \\
\hline SoyChlor ${ }^{4}$ & 0 & 0 & 5.51 & 0 \\
\hline Salt & 0.21 & 0.21 & 0.19 & 0.5 \\
\hline Magnesium oxide & 0.32 & 0.35 & 0.3 & 0 \\
\hline Calcium carbonate & 0 & 2.30 & 1.84 & 1.2 \\
\hline Sodium bicarbonate & 0 & 0 & 0 & 0.8 \\
\hline \multicolumn{5}{|l|}{ Chemical composition 5} \\
\hline DM, \% & 45.2 & 44.7 & 46.4 & 90.9 \\
\hline $\mathrm{CP}, \%$ & 14.1 & 14.1 & 14.1 & 20.2 \\
\hline NDF, \% & 42.2 & 40.5 & 39.7 & 16.1 \\
\hline $\mathrm{NFC}^{6}, \%$ & 34.5 & 34.1 & 32.6 & 51.3 \\
\hline EE, \% & 3.1 & 3.1 & 3.8 & 3.2 \\
\hline $\mathrm{Ca}, \%$ & 0.24 & 1.23 & 1.21 & 0.82 \\
\hline $\mathrm{P}, \%$ & 0.39 & 0.38 & 0.37 & 0.39 \\
\hline $\mathrm{Mg}, \%$ & 0.44 & 0.42 & 0.49 & 0.22 \\
\hline $\mathrm{K}, \%$ & 1.14 & 1.17 & 1.21 & 1.13 \\
\hline $\mathrm{S}, \%$ & 0.32 & 0.30 & 0.40 & 0.20 \\
\hline $\mathrm{Na}, \%$ & 0.11 & 0.11 & 0.10 & 0.49 \\
\hline $\mathrm{Cl}, \%$ & 0.24 & 0.24 & 0.76 & 0.36 \\
\hline
\end{tabular}


Table 1. Cont.

\begin{tabular}{ccccc}
\hline \multirow{2}{*}{ Item } & \multicolumn{3}{c}{ Prepartum Diet $^{\mathbf{1}}$} & \multirow{2}{*}{ Calf Starter } \\
\cline { 2 - 4 } & Low Ca & High Ca & Low DCAD & \\
\hline $\mathrm{DCAD}^{7}, \mathrm{mEq} / \mathrm{kg}$ & 86 & 95 & -115 & 231 \\
$\mathrm{NEL}^{8}, \mathrm{Mcal} / \mathrm{kg}$ & 1.49 & 1.48 & 1.48 & \multirow{2}{*}{2.76} \\
$\mathrm{ME}^{9}, \mathrm{Mcal} / \mathrm{kg}$ & 2.31 & 2.29 & 2.29 & 2 \\
\hline
\end{tabular}

${ }^{1}$ Low Ca diet $(0.24 \% \mathrm{Ca},+86 \mathrm{mEq} / \mathrm{kg})$; high Ca diet $(1.23 \% \mathrm{Ca},+95 \mathrm{mEq} / \mathrm{kg})$, low dietary cation-anion difference (DCAD; high Ca diet supplemented with SoyChlor; $1.28 \% \mathrm{Ca},-115 \mathrm{mEq} / \mathrm{kg}$; all dry matter (DM) basis). ${ }^{2}$ The cow mineral contained per kilogram DM: 16,000 mg Zn, 10,000 mg Mn, 4000 mg Cu, 800 mg Fe, 150 mg I, 120 mg $\mathrm{Co}$, and $80 \mathrm{mg}$ Se. The calf mineral contained per kilogram DM: 240,000 mg Ca, 67,500 mg Mg, 20,000 mg Zn, 4290 $\mathrm{mg} \mathrm{Cu}, 200 \mathrm{mg}$ I, and $100 \mathrm{mg} \mathrm{Co}{ }^{3}$ The vitamin supplement for the cows contained per kilogram DM: 1,000,000 IU vitamin A, 360,000 IU vitamin D3, and 15,000 IU vitamin E. The vitamin supplement included in the calf starter contained (IU/ $\mathrm{kg} \mathrm{DM}$ ) vitamin A, 1,300,000; vitamin D, 360,000; and vitamin E, 12,000. ${ }^{4}$ Contained $46 \%$ crude protein, $12.1 \% \mathrm{Cl}, 1.2 \% \mathrm{Ca}, 0.4 \% \mathrm{Mg}, 0.32 \% \mathrm{~S}$, and $1.15 \% \mathrm{~K}$ (all DM basis; Mehre Bisotun Corporation, Tehran, Iran). ${ }^{5}$ Determined on samples pooled by week. All values except DM are expressed on a DM basis $(n=8)$. ${ }^{6}$ Non-fiber carbohydrate 100-((NDF-neutral detergent insoluble CP) $+\mathrm{CP}+$ ash + fat $).{ }^{7}$ Dietary cation-anion difference $\left(\left(\mathrm{Na}^{+}+\mathrm{K}^{+}\right)-\left(\mathrm{Cl}^{-}+\mathrm{S}^{-2}\right)\right) .{ }^{8}$ Based on tabular values (Cornell Net Carbohydrate and Protein System; [25]). ${ }^{9}$ Calculated based on the chemical analysis [26].

\subsection{Calving and Calf Management}

Calving ease was scored using a 4-point scale $(1=$ no assistance needed; $2=$ light assistance by one person without the use of mechanical traction; 3 = mechanical extraction of the calf with an obstetric calf-puller; and $4=$ severe dystocia, surgery or fetotomy needed) according to [27]. Calves were removed from their dams immediately after birth, weighed, and the calves' navels were dipped prophylactically in $2 \%$-iodine solution. Calves were transferred to individual pens $(2.9 \times 1.1 \mathrm{~m}$; length $\times$ width) located in an open-sided barn equipped with large ceiling fans. The calf pens were bedded with straw.

On their day of birth $(\mathrm{d} 0)$, all calves consumed $3.5 \mathrm{~L}$ of colostrum from their dams in two feedings ( $2 \mathrm{~L}$ within $1 \mathrm{~h}$ after birth and $1.5 \mathrm{~L} 8 \mathrm{~h}$ later) by nipple bottle. From day 1 to 49 , calves received $6 \mathrm{~L}$ of pasteurized whole milk containing $3.25 \% \pm 0.12 \%$ fat, $2.98 \% \pm 0.06 \%$ protein, $4.88 \% \pm 0.05 \%$ lactose, and $11.77 \% \pm 0.15 \%$ total solids twice daily at $09: 00 \mathrm{~h}$ and 19:00 $\mathrm{h}$. Starting on day 50 the quantity of milk was reduced to $3 \mathrm{~L}$ of milk/d and the calves were only fed once (at 09:00 h). Calves were weaned on day 56 but remained in individual pens until the end of the experiment $(70 \mathrm{~d})$. The calves had access to a dry TMR (i.e., calf starter) containing $90 \%$ concentrate and $10 \%$ alfalfa hay (Table 1 ). Starter and fresh water were offered for ad libitum intake from $\mathrm{d} 1$ until the end of experiment.

\subsection{Colostrum Collection and Analyses}

Dams were milked within 30 min after calving, the colostrum was weighted and two colostrum samples were taken. One sample (ca. $250 \mathrm{~mL}$ ) was used to measure the specific gravity with a colostrometer (Funke-Gerber Labortechnik GmbH, Berlin, Germany). The specific gravity, determined at $22{ }^{\circ} \mathrm{C}$, was used to estimate the Ig content of the colostrum [28]. A Brix refractometer (Model LH-Y12, Atago Co., Ltd., Tokyo, Japan) was used to determine the concentration of IgG [29]. A second sample $(30 \mathrm{~mL})$ was frozen at $-20^{\circ} \mathrm{C}$ to measure the colostrum composition. After thawing, colostrum samples were diluted (1:5, vol:vol) with phosphate buffer saline ( $\mathrm{pH} 7.3)$ and homogenized by ultrasound mixing ( $5 \mathrm{~min}$ ). Samples were analyzed for fat, protein, lactose, and solids-not-fat (SNF) by an infrared analyzer (MilkoScan BN, Foss Electric, Hillerød, Denmark).

\subsection{Blood Analyses}

Blood samples from each calf were collected by jugular vein puncture using a $10 \mathrm{~mL}$ serum Vacutainer ${ }^{\circledR}$ (Becton Dickinson, Franklin Lakes, NJ, USA), approximately 20 min before colostrum feeding on $\mathrm{d} 0$ and $1,7,35$, and 70 at $3 \mathrm{~h}$ after the morning feeding. The blood samples were stored at room temperature to allow clotting. Samples were subsequently centrifuged at $3000 \times g$ for $15 \mathrm{~min}$. 
The serum was decanted into three aliquots and stored at $-20{ }^{\circ} \mathrm{C}$ until analysis. Serum samples were analyzed for $\mathrm{Ca}, \mathrm{Mg}$, and $\mathrm{P}$ by the cresolphthalein-complexone method, xildyl-blue method, and UV-test, respectively, using a diagnostic kit (Pars Azmoon Co., Tehran, Iran). The kit was used according to the manufacturer's instructions. Samples were analyzed using an auto analyzer (Alcyon 300, Abbott Laboratories, Abbott Park, IL, USA).

The serum glucose concentration was measured by an enzymatic assay (GOD-PAD, Pars Azmoon Co., Tehran, Iran). Blood urea-N (BUN), total protein, albumin, alanine aminotransferase (ALT), and aspartate aminotransferase (AST) were measured using commercial kits (Pars Azmoon Co., Tehran, Iran) according to the manufacturer's instructions. All analyses were performed in duplicates using an autoanalyzer (Abbott Alycon 300, Abbott Park, IL, USA,). Before any samples were processed, the analyzer was calibrated with control sera containing known concentrations of $N$ and $P$ (TrueLab $N^{\circledR}$ and TrueLabP ${ }^{\circledR}$, Pars Azmoon Co., Tehran, Iran) and a standard calibration solution (TrueCal $\mathrm{U}^{\circledR}$, Pars Azmoon Co., Tehran, Iran). Beta-hydroxybutyrate (BHB) concentrations were determined by an enzymatic colorimetric method using a commercial kit (Randox Laboratories Ltd., Ardmore, UK) and the same autoanalyzer. Globulin concentrations were calculated by subtracting the albumin from the total protein content.

\subsection{Feed Intake, Body Weight, and Analyses}

Starter feed offered and refused was recorded weekly for each calf and used to calculate average daily feed intake. Starter feed and refusals were sampled once per week during the entire experiment. Samples of the starter feed (pooled by week) and refusals (pooled monthly by calf) were frozen at $-20{ }^{\circ} \mathrm{C}$ until analyzed. Milk intake was recorded for each feeding. The BW of the calves was recorded at birth and once per week during the preweaning ( $\mathrm{d}$ 0-55) and postweaning phase ( $\mathrm{d}$ 56-70). Preweaning, postweaning, and overall means for ADG and feed efficiency (FE; kg BW gain/kg total DM intake (milk DM + starter feed DM)) were calculated.

Prior to analyses, feed samples were ground through a 1-mm screen using a Wiley mill (Arthur Thomas Co., Philadelphia, PA). Dry matter was determined by oven-drying at $65{ }^{\circ} \mathrm{C}$ until constant weight was reached. For $\mathrm{CP}$ analysis $(\mathrm{N} \times 6.25)$, samples were analyzed by Kjeldahl titration $(\mathrm{Kjeltec}$ 1030 Auto Analyzer, Tecator, Höganäs, Sweden; [30]); method 988.05. Ether extract (EE) and ash contents were analyzed according to [30]; method 920.39 and 924.05, respectively. Neutral detergent fiber was analyzed according to [31] using heat stable $\alpha$ amylase (100 $\mu \mathrm{L} / 0.5 \mathrm{~g}$ of sample) and sodium sulfite. All chemical analyses were performed in duplicates.

\subsection{Health Monitoring, Fecal Scoring, and Medical Treatment}

Calf health was monitored daily by a veterinarian who was unaware of the treatment assignment. The consistency of the feces was scored daily on a scale of $0-3,(0=$ normal consistency, $1=$ semi formed or pasty, 2 = loose, and 3 = watery, sifts through bedding) using the Wisconsin-Madison calf health scoring chart [32]. To describe the duration of diarrhea, the number of days with an abnormal fecal score (AFS $\geq 2$ ) was recorded for each calf.

Calves with diarrhea (fecal score $\geq 2$ ) received a water-based oral electrolyte solution $(6 \mathrm{~L} / \mathrm{calf}$ per day in 4 equal meals for three consecutive days) and sulfadimidine sodium ( $220 \mathrm{mg} / \mathrm{kg}$ BW for 3 consecutive days; 6 mL/10 kg BW; Tolide Darouhai Dami Co., Tehran, Iran). Non-responding calves were treated for three more days with oxytetracycline (Oxyject L. A.; $1 \mathrm{~mL} / 10 \mathrm{~kg}$ BW on the first $2 \mathrm{~d}$; Rooyan Darou Co., Tehran, Iran) and Pantrisul (40 mg Trimethoprim and $200 \mathrm{mg}$ Sulfamethoxazole per $\mathrm{mL}, 1 \mathrm{~mL} / 10 \mathrm{~kg}$ BW on the first two days; Pantex Holland B.V., Hapert, The Netherlands). To treat pneumonia, calves were administered oxytetracycline (Tenaline 20\% L. A.; $1 \mathrm{~mL} / 10 \mathrm{~kg}$ BW on day 1 and 3; Ceva Sante Animale, Libourne, France), florfenicol (F-nex 300; $1.5 \mathrm{~mL} / 10 \mathrm{~kg}$ BW for three consecutive days; Razak Laboratories Co., Karaj, Iran), and flunixin meglumine (Flunixin 5\%; $1 \mathrm{~mL} / 10 \mathrm{~kg}$ BW for three consecutive days; Razak Laboratories Co., Karaj, Iran). Drug usage (type of medication, frequency, and duration of the treatment) was recorded throughout the experiment. 


\subsection{Statistical Analysis}

All statistical analyses were conducted using SAS (version 9.4, SAS Institute Inc., Cary, NC, USA). Data were subjected to an ANOVA using the MIXED procedure (Proc Mixed). Feed intake, ADG, feed conversion efficiency, BW, and blood variables were sampled at several time points and therefore sampling time (day) was considered as repeated measure for the preweaning (day 0-55) and postweaning (day 56-70) phase as well as the complete duration of the experiment (day 0-70). The statistical model included fixed effects of treatment, sex, period, and interaction among treatments and period and calf as a random effect. Birth weight and colostrum data were analyzed with the same model described above but without repeated measures and the effect of sampling time. The effect of dietary treatment on the categorical responses (fecal scores and drug usage) was analyzed by PROC GLIMMIX with repeated measures. The best-fitting covariance structure (autoregressive structure type 1) was selected based on the lowest Akaike information criterion corrected for sample size [33]. Results are presented as least squares means (LSM).

Differences among treatment LSM were determined using a Tukey test. Treatment differences were declared significant at $p<0.05$. Tendencies are discussed at $0.05 \leq p<0.10$.

\section{Results}

\subsection{Calving Ease, Colostrum Yield, and Composition}

Prepartum Ca restriction tended to result in a higher yield of colostrum (low $\mathrm{Ca}=8.8 \mathrm{~kg}$, Table 2) compared to cows in the high Ca group ( $5.3 \mathrm{~kg} ; p=0.06)$, while feeding low DACD had no effect on colostrum production. Treatments did not affect the percentage of fat, protein, lactose, and SNF but yields of fat, lactose, and SNF (kg) increased in response to low Ca $(p<0.01)$. Cows offered high Ca produced less true protein in comparison to low $\mathrm{Ca}(p<0.01)$.

Table 2. Colostrum yield and composition of Holstein cows fed diets fed low or high Ca or a negative dietary cation-anion difference (DCAD) for $21 \mathrm{~d}$ before calving $(n=12)$.

\begin{tabular}{cccccc}
\hline \multirow{2}{*}{ Item } & \multicolumn{3}{c}{ Treatment $^{\mathbf{1}}$} & \multirow{2}{*}{ SEM } & \multirow{2}{*}{-Value } \\
\cline { 2 - 3 } & Low Ca & High Ca & Low DCAD & & \\
\hline First milking (colostrum) & & & & \\
Yield, kg & 8.81 & 5.39 & 6.75 & 1.40 & 0.06 \\
Fat, \% & 4.81 & 5.07 & 4.94 & 0.10 & 0.17 \\
True protein, $\%$ & 14.4 & 14.6 & 14.7 & 0.14 & 0.33 \\
Lactose, $\%$ & 3.7 & 3.6 & 3.6 & 0.06 & 0.45 \\
Solids-not-fat, $\%$ & 17.8 & 18.1 & 18.0 & 0.15 & 0.31 \\
Fat, kg & $0.40^{\mathrm{a}}$ & $0.27^{\mathrm{b}}$ & $0.32^{\mathrm{b}}$ & 0.02 & $<001$ \\
True protein, $\mathrm{kg}$ & $1.22^{\mathrm{a}}$ & $0.80^{\mathrm{b}}$ & $0.99^{\mathrm{ab}}$ & 0.08 & $<001$ \\
Lactose, $\mathrm{kg}$ & $0.31^{\mathrm{a}}$ & $0.20^{\mathrm{b}}$ & $0.24^{\mathrm{b}}$ & 0.02 & $<001$ \\
Solids-not-fat, $\mathrm{kg}$ & $1.55^{\mathrm{a}}$ & $0.98^{\mathrm{b}}$ & $1.20^{\mathrm{b}}$ & 0.10 & $<001$ \\
\hline
\end{tabular}

${ }^{1}$ Low Ca diet $(0.24 \% \mathrm{Ca},+86 \mathrm{mEq} / \mathrm{kg}) ;$ high Ca diet $(1.23 \% \mathrm{Ca},+95 \mathrm{mEq} / \mathrm{kg})$, low DCAD (high Ca diet supplemented with SoyChlor; $1.28 \% \mathrm{Ca},-115 \mathrm{mEq} / \mathrm{kg}$; all DM basis). ${ }^{\mathrm{a}, \mathrm{b}}$ Different superscripts indicate significant differences between the respective groups.

The Brix value and specific density of the colostrum were not affected by the dietary treatment (Table 3). Calving ease was similar among treatments 
Table 3. Colostrum quality, calving ease of Holstein cows fed low or high Ca or a negative dietary cation-anion difference (DCAD) for 21 days before calving and the rectal temperature of their calves at birth $(n=12)$.

\begin{tabular}{cccccc}
\hline \multirow{2}{*}{ Item } & \multicolumn{3}{c}{ Treatment $^{\mathbf{1}}$} & \multirow{2}{*}{ SEM } & \multirow{2}{*}{$\boldsymbol{p}$-Value } \\
\cline { 2 - 4 } & Low Ca & High Ca & Low DCAD & & \\
\hline Brix value colostrum, $\%$ & 25.83 & 27.26 & 26.34 & 1.5 & 0.82 \\
Colostrum density, g/cm ${ }^{3}$ & 1.057 & 1.059 & 1.061 & 2.1 & 0.27 \\
Calving ease ${ }^{2}$ & 1.25 & 1.33 & 1.33 & 0.20 & 0.80 \\
Rectal temperature at birth, ${ }^{\circ} \mathrm{C}$ & 38.26 & 38.14 & 38.47 & 0.12 & 0.52 \\
\hline
\end{tabular}

${ }^{1}$ Low Ca diet $(0.24 \% \mathrm{Ca},+86 \mathrm{mEq} / \mathrm{kg})$; high Ca diet $(1.23 \% \mathrm{Ca},+95 \mathrm{mEq} / \mathrm{kg})$, low DCAD (high Ca diet supplemented with SoyChlor; $1.28 \% \mathrm{Ca},-115 \mathrm{mEq} / \mathrm{kg}$; all DM basis). ${ }^{2}$ Recorded using a 4-point scale ( $1=$ no assistance needed; $2=$ light assistance by one person without the use of mechanical traction; $3=$ mechanical extraction of the calf with an obstetric calf-puller; and 4 = severe dystocia, surgery or fetotomy needed).

\subsection{Mineral and Intermediary Metabolism}

The Ca level or DCAD of the prepartum diet did not affect the serum concentrations of $\mathrm{Ca}, \mathrm{P}$, and $\mathrm{Mg}$ of the calves during the preweaning and postweaning phase or the complete length of the experiment (Table 4). There was no interaction between treatment and time of these parameters. Serum concentrations of $\mathrm{Ca}$ and $\mathrm{P}$ were elevated at birth and day $1(p<0.01)$ but decreased subsequently until day 70 .

Table 4. Blood chemistry parameters of calves from Holstein dams fed low or high Ca or a negative dietary cation-anion difference (DCAD) for 21 days before calving $(n=12)$.

\begin{tabular}{|c|c|c|c|c|c|c|c|}
\hline \multirow{2}{*}{ Item $^{1}$} & \multicolumn{3}{|c|}{ Treatment $^{2}$} & \multirow{2}{*}{ SEM } & \multicolumn{3}{|c|}{$p$-Value } \\
\hline & Low Ca & High Ca & Low DCAD & & Trt. & Day & Trt $\times$ Day \\
\hline \multicolumn{8}{|l|}{ Glucose, mg/dL } \\
\hline Preweaning (d 0-55) & 97.86 & 93.74 & 105.63 & 6.2 & 0.37 & 0.11 & 0.69 \\
\hline Postweaning (d 70) & 94.54 & 96.93 & 99.87 & 2.6 & 0.78 & & \\
\hline Overall (d 0-70) & 97.06 & 94.54 & 100.83 & 4.4 & 0.59 & 0.05 & 0.27 \\
\hline \multicolumn{8}{|l|}{ Beta-hydroxybutyrate, $\mathrm{mM}$} \\
\hline Preweaning (d 0-55) & 0.18 & 0.17 & 0.19 & 0.01 & 0.14 & $<0.01$ & 0.15 \\
\hline Postweaning (d 70) & 0.27 & 0.30 & 0.34 & 0.02 & 0.32 & & \\
\hline Overall (d 0-70) & 0.19 & 0.20 & 0.20 & 0.01 & 0.35 & $<0.01$ & 0.24 \\
\hline \multicolumn{8}{|l|}{$\mathrm{AST}^{3}, \mathrm{U} / \mathrm{L}$} \\
\hline Preweaning (d 0-55) & 26.82 & 27.85 & 25.33 & 1.7 & 0.58 & 0.82 & 0.43 \\
\hline Postweaning (d 70) & 38.20 & 41.54 & 37.13 & 5.0 & 0.82 & & \\
\hline Overall (d 0-70) & 29.67 & 31.25 & 28.38 & 1.56 & 0.46 & $<0.01$ & 0.94 \\
\hline \multicolumn{8}{|l|}{$\mathrm{ALT}^{4}, \mathrm{U} / \mathrm{L}$} \\
\hline Preweaning (d 0-55) & 9.48 & 9.50 & 8.73 & 0.63 & 061 & 0.08 & 0.55 \\
\hline Postweaning (d 70) & 13.24 & 15.43 & 12.67 & 1.6 & 0.50 & & \\
\hline Overall (d 0-70) & 10.44 & 10.93 & 9.75 & 0.58 & 0.34 & $<0.01$ & 0.69 \\
\hline \multicolumn{8}{|l|}{$\mathrm{Ca}, \mathrm{mM}$} \\
\hline Preweaning (d 0-55) & 3.03 & 3.12 & 2.98 & 0.09 & 0.33 & 0.01 & 0.39 \\
\hline Postweaning (d 70) & 2.94 & 2.82 & 2.70 & 0.09 & 0.40 & & \\
\hline Overall (d 0-70) & 3.02 & 3.04 & 2.91 & 0.07 & 0.44 & $<0.01$ & 0.22 \\
\hline \multicolumn{8}{|l|}{$\mathrm{P}, \mathrm{mM}$} \\
\hline Preweaning (d 0-55) & 2.42 & 2.55 & 2.63 & 0.07 & 0.24 & $<0.01$ & 0.09 \\
\hline Postweaning (d 70) & 2.64 & 2.57 & 2.68 & 0.11 & 0.70 & & \\
\hline Overall (d 0-70) & 2.53 & 2.56 & 2.65 & 0.06 & 0.52 & $<0.01$ & 0.08 \\
\hline \multicolumn{8}{|l|}{$\mathrm{Mg}, \mathrm{mM}$} \\
\hline Preweaning (d 0-55) & 0.79 & 0.78 & 0.74 & 0.02 & 0.21 & 0.25 & 0.06 \\
\hline Postweaning (d 70) & 0.76 & 0.72 & 0.71 & 0.04 & 0.69 & & \\
\hline Overall (d 0-70) & 0.78 & 0.77 & 0.74 & 0.02 & 0.15 & 0.19 & 0.20 \\
\hline \multicolumn{8}{|l|}{$\mathrm{K}, \mathrm{mM}$} \\
\hline Preweaning (d 0-55) & $4.13^{b}$ & $4.16^{\mathrm{b}}$ & $4.44^{\mathrm{a}}$ & 0.06 & 0.001 & $<0.01$ & $<0.01$ \\
\hline Postweaning (d 70) & 3.86 & 3.97 & 3.81 & 0.09 & 0.51 & & \\
\hline Overall (d 0-70) & $4.06^{\mathrm{b}}$ & $4.09^{b}$ & $4.28^{\mathrm{a}}$ & 0.08 & $<0.01$ & $<0.01$ & $<0.01$ \\
\hline
\end{tabular}

${ }_{1}^{1}$ Blood samples were collected before the first colostrum feeding and on $\mathrm{d} 1,7,35$, and 70 before feeding. ${ }^{2}$ Calves born to cows fed low Ca diet $(0.24 \% \mathrm{Ca},+86 \mathrm{mEq} / \mathrm{kg})$, high Ca diet $(1.23 \% \mathrm{Ca},+95 \mathrm{mEq} / \mathrm{kg})$, and low DCAD (high Ca diet supplemented with SoyChlor; $1.28 \% \mathrm{Ca},-115 \mathrm{mEq} / \mathrm{kg}$; all DM basis) for $21 \mathrm{~d}$ before calving. ${ }^{3}$ Aspartate aminotransferase. ${ }^{4}$ Alanine aminotransferase. ${ }^{\mathrm{a}, \mathrm{b}}$ Different superscripts indicate significant differences between the respective groups. 
Before weaning (day 0-55), calves born to low DCAD dams had greater serum $\mathrm{K}$ concentrations $(4.44 \mathrm{mg} / \mathrm{dL})$ compared to those born to high Ca $(4.16 \mathrm{mg} / \mathrm{dL})$ and low Ca $(4.13 \mathrm{mg} / \mathrm{dL})$ dams $(p<0.001)$ but there were no differences in serum $\mathrm{K}$ concentrations among treatments after weaning.

There was no effect of dietary treatment or the interaction between treatment and age for total serum protein, albumin, and globulin concentrations during preweaning, postweaning, or the entire length of the experiments (Table 5). In addition, there was no effect of dietary treatment on BUN.

Table 5. Protein metabolism parameters of calves $(n=12)$ from Holstein dams fed low or high Ca or a negative dietary cation-anion difference (DCAD) for 21 days before calving $(n=12)$.

\begin{tabular}{|c|c|c|c|c|c|c|c|}
\hline \multirow{2}{*}{ Item $^{1}$} & \multicolumn{3}{|c|}{ Treatment $^{2}$} & \multirow{2}{*}{ SEM } & \multicolumn{3}{|c|}{$p$-Value } \\
\hline & Low Ca & High Ca & Low DCAD & & Trt & Day & Trt $\times$ Day \\
\hline \multicolumn{8}{|l|}{ Total protein, mg/dL } \\
\hline Preweaning (d 0-55) & 6.89 & 7.20 & 7.23 & 0.21 & 0.36 & $<0.01$ & 0.21 \\
\hline Postweaning (d 56-70) & 7.33 & 7.02 & 7.4 & 0.28 & 0.59 & & \\
\hline Overall (d 0-70) & 6.93 & 7.13 & 725 & 0.19 & 0.48 & $<0.01$ & 0.40 \\
\hline \multicolumn{8}{|l|}{ Albumin, mg/dL } \\
\hline Preweaning (d 0-55) & 3.05 & 3.27 & 3.23 & 0.09 & 0.17 & $<0.01$ & 0.14 \\
\hline Postweaning (d 56-70) & 3.63 & 3.76 & 3.86 & 0.10 & 0.24 & & \\
\hline Overall (d 0-70) & 3.20 & 3.38 & 3.40 & 0.07 & 0.12 & $<0.01$ & 0.12 \\
\hline \multicolumn{8}{|l|}{ Globulin, mg/dL } \\
\hline Preweaning (d 0-55) & 3.84 & 3.96 & 3.90 & 0.20 & 0.19 & $<0.01$ & 0.32 \\
\hline Postweaning (d 56-70) & 3.70 & 3.26 & 3.50 & 0.25 & 0.50 & & \\
\hline Overall (d 0-70) & 3.72 & 3.74 & 3.86 & 0.17 & 0.83 & $<0.01$ & 0.41 \\
\hline \multicolumn{8}{|l|}{ Albumin:globulin } \\
\hline Preweaning (d 0-55) & 0.86 & 0.90 & 0.88 & 0.05 & 0.91 & $<0.01$ & 0.24 \\
\hline Postweaning (d 55-70) & 1.03 & 1.18 & 1.15 & 0.08 & 0.36 & & \\
\hline Overall (d 0-70) & 0.90 & 0.97 & 0.95 & 0.04 & 0.63 & $<0.01$ & 0.36 \\
\hline \multicolumn{8}{|l|}{ Urea nitrogen, mg/dL } \\
\hline Preweaning (d 0-55) & 27.9 & 32.3 & 31.2 & 2.13 & 0.16 & 0.21 & 0.60 \\
\hline Postweaning (d 70) & 27.8 & 29.3 & 31.3 & 1.47 & 0.22 & & \\
\hline Overall (d 0-70) & 27.8 & 33.1 & 31.0 & 1.73 & 0.10 & 0.35 & 0.48 \\
\hline
\end{tabular}

${ }^{1}$ Blood samples were collected before the first colostrum feeding and on $\mathrm{d} 1,7,35$, and 70 before feeding. ${ }^{2}$ Calves born to cows fed low Ca diet $(0.24 \% \mathrm{Ca},+86 \mathrm{mEq} / \mathrm{kg})$; high Ca diet $(1.23 \% \mathrm{Ca},+95 \mathrm{mEq} / \mathrm{kg})$, and low DCAD (high Ca diet supplemented with SoyChlor; $1.28 \% \mathrm{Ca},-115 \mathrm{mEq} / \mathrm{kg}$; all DM basis) for $21 \mathrm{~d}$ before calving.

Indices related to energy metabolism, such as glucose and $\mathrm{BHB}$, did not differ among treatments before weaning (Table 4). After weaning and over the entire length of the experiment, BHB concentrations increased markedly $(p<0.001)$.

\subsection{Feed Intake and Growth Performance}

Calves born to cows receiving the low DCAD diet consumed less starter and total feed (starter and milk combined) during the first week $(p<0.01)$. Treatment had no effect on total DMI and starter feed intake during the preweaning or postweaning and the overall experiment.

The birth weight of the calves (Table 6) was similar among treatments $(43.32,42.63$, and $41.06 \mathrm{~kg}$ for calves born to low Ca, high Ca, and low DCAD); while calves born to low DCAD diet had lower BW in wk 1 in comparison to calves born to low Ca and high Ca cows (Figure $1 ; p=0.01 ; 39.30$ vs. 45.04 and $43.67 \mathrm{~kg})$. In addition, they had lower BW at wk 2 ( $p=0.02)$ compared to low Ca (42.55 vs. $47.09 \mathrm{~kg})$. Due to this, there was an interaction $(p=0.01)$ between treatment and age of the calves for BW during preweaning $(p=0.04)$ and the entire length of the experiment $(p=0.02)$. Body weight at weaning (day 56) tended $(p=0.08)$ to be lower for calves born to cows that received low DCAD compared to calves born to low Ca and high Ca cows (69.13 vs. 75.48 and $74.91 \mathrm{~kg}$, respectively). Post weaning BW was similar at day 70. 
Table 6. Body weight, average daily gain, starter feed intake, and feed efficiency of calves from Holstein dams fed low or high Ca or a negative dietary cation-anion difference (DCAD) for 21 days before calving $(n=12)$.

\begin{tabular}{|c|c|c|c|c|c|c|c|}
\hline \multirow{2}{*}{ Item } & \multicolumn{3}{|c|}{ Treatment $^{1}$} & \multirow{2}{*}{ SEM } & \multicolumn{3}{|c|}{$p$-Value } \\
\hline & Low Ca & High Ca & Low DCAD & & Trt & Day & Trt $\times$ Day \\
\hline \multicolumn{8}{|l|}{ Starter intake, kg DM/d } \\
\hline Preweaning (d 0-55) & 0.39 & 0.40 & 0.38 & 0.04 & 0.88 & $<0.01$ & 0.05 \\
\hline Postweaning (d 56-70) & 1.98 & 1.63 & 1.58 & 0.19 & 0.20 & $<0.01$ & 0.88 \\
\hline Overall (d 0-70) & 0.71 & 0.64 & 0.62 & 0.05 & 0.51 & $<0.01$ & 0.39 \\
\hline \multicolumn{8}{|l|}{ Total DMI, kg/d } \\
\hline Preweaning (d 0-55) & 1.03 & 1.04 & 1.01 & 0.04 & 0.91 & $<0.01$ & 0.02 \\
\hline Postweaning (d 56-70) & 1.98 & 1.63 & 1.58 & 0.19 & 0.20 & $<0.01$ & 0.88 \\
\hline Overall (d 0-70) & 1.23 & 1.16 & 1.14 & 0.06 & 0.55 & $<0.01$ & 0.53 \\
\hline \multicolumn{8}{|l|}{ Body weight $^{2}, \mathrm{~kg}$} \\
\hline Initial (d 0) & 43.32 & 42.63 & 41.06 & 1.31 & 0.48 & & \\
\hline At weaning (d 55) & 75.48 & 74.91 & 69.13 & 2.0 & 0.08 & & \\
\hline End of study (d 70) & 89.58 & 86.45 & 82.37 & 3.71 & 0.21 & & \\
\hline Preweaning (d 0-55) & $57.68^{\mathrm{a}}$ & $57.32^{\mathrm{a}}$ & $53.12^{b}$ & 1.32 & 0.05 & $<0.01$ & 0.04 \\
\hline Postweaning (d 56-70) & 85.70 & 83.65 & 79.94 & 2.54 & 0.32 & $<0.01$ & 0.15 \\
\hline Overall (d 0-70) & 63.24 & 62.56 & 58.42 & 1.57 & 0.08 & $<0.01$ & 0.02 \\
\hline \multicolumn{8}{|l|}{$\mathrm{ADG}, \mathrm{kg} / \mathrm{d}$} \\
\hline Preweaning (d 0-55) & 0.58 & 0.55 & 0.38 & 0.08 & 0.29 & $<0.01$ & 0.46 \\
\hline Postweaning (d 55-70) & 1.01 & 0.83 & 0.94 & 0.07 & 0.22 & 0.53 & 0.24 \\
\hline Overall (d 0-70) & 0.66 & 0.62 & 0.59 & 0.03 & 0.30 & $<0.01$ & 0.02 \\
\hline \multicolumn{8}{|l|}{ Feed efficiency ${ }^{3}$} \\
\hline Preweaning (d 0-55) & 0.56 & 0.46 & 0.37 & 0.08 & 0.32 & $<0.01$ & 0.29 \\
\hline Postweaning (d 56-70) & 0.53 & 0.60 & 0.65 & 0.06 & 0.56 & $<0.01$ & 0.14 \\
\hline Overall (d 0-70) & 0.55 & 0.55 & 0.52 & 0.02 & 0.63 & $<0.01$ & 0.11 \\
\hline
\end{tabular}

${ }^{1}$ Calves born to cows fed low Ca diet $(0.24 \% \mathrm{Ca},+86 \mathrm{mEq} / \mathrm{kg})$; high Ca diet $(1.23 \% \mathrm{Ca},+95 \mathrm{mEq} / \mathrm{kg})$, and low DCAD (high Ca diet supplemented with SoyChlor $\left(1.28 \% \mathrm{Ca},-115 \mathrm{mEq} / \mathrm{kg}\right.$; all DM basis) for $21 \mathrm{~d}$ before calving. ${ }^{2}$ Body weight was measured weekly throughout the experiment. ${ }^{3}$ Feed efficiency was calculated by dividing average daily gain by average total daily DM intake. ${ }^{a, b}$ Different superscripts indicate significant differences between the respective groups.

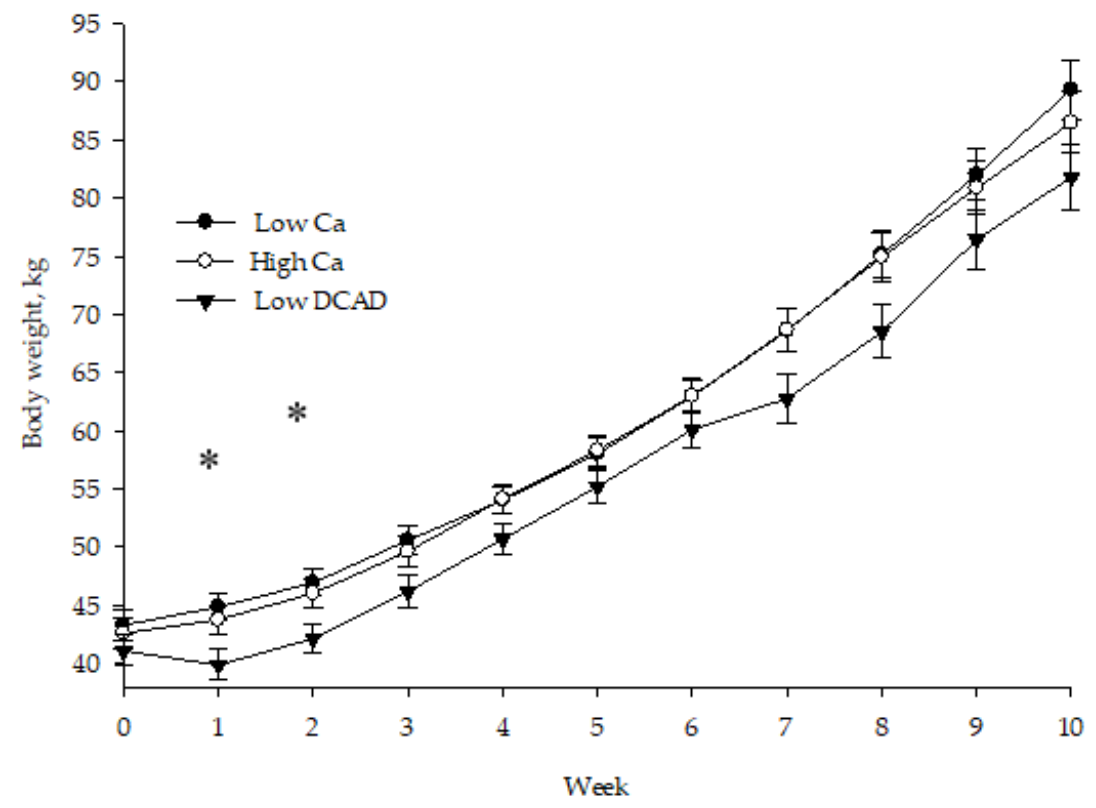

Figure 1. Body weight development of neonate calves from Holstein cows fed low $\mathrm{Ca}$, high $\mathrm{Ca}$, or a negative dietary cation-anion difference (low DCAD) for $21 \mathrm{~d}$ before calving. * Significant differences between groups are indicated by asterisks $(p<0.05)$. 
Average daily gain was not affected by treatment during the pre- and postweaning phase and the whole experiment but there was an interaction $(p=0.02)$ between treatment and age of the calves for ADG. Calves born to a low DCAD diet had lower ADG in week 1 in comparison to calves born to low $\mathrm{Ca}$ and high Ca cows (Figure $2 ; p=0.01 ;-0.07$ vs. $0.22,0.17 \mathrm{~kg}$ ). A tendency for lower $\operatorname{ADG}(p=0.07)$ was observed at week 7 of study in calves born to a low DCAD cow as well.

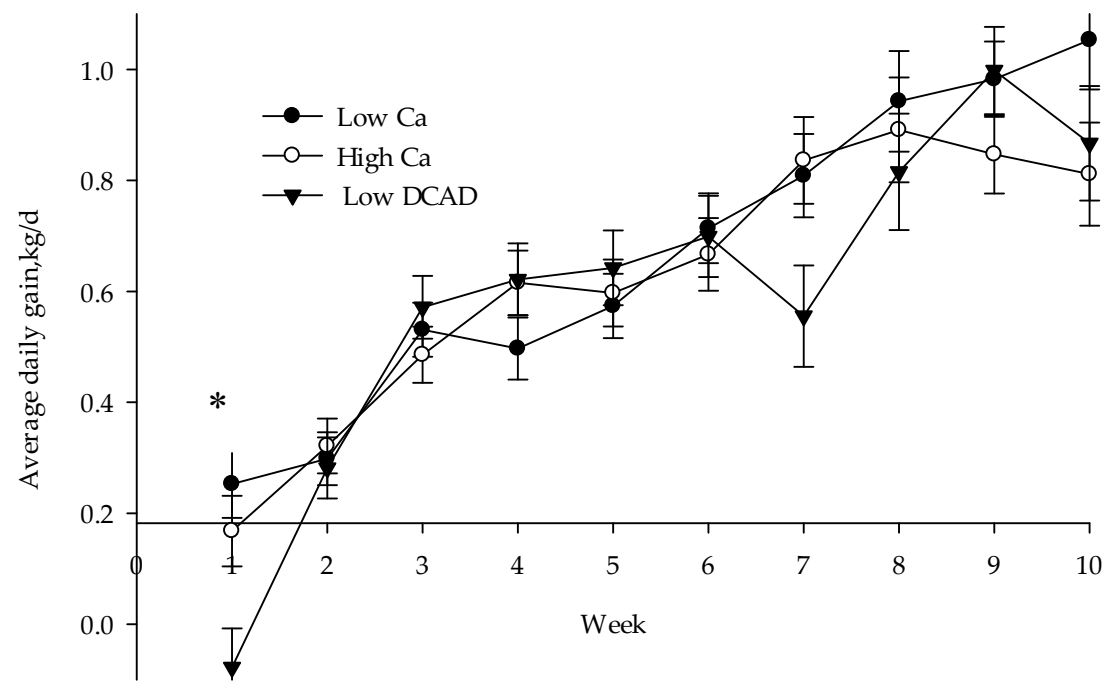

Figure 2. Body weight development of neonate calves from Holstein cows fed low Ca, high Ca, or a negative dietary cation-anion difference (low DCAD) for $21 \mathrm{~d}$ before calving. ${ }^{*}$ Significant differences between groups are indicated by asterisks $(p<0.05)$.

No differences in feed efficiency were detected between treatments and interactions between treatment and time during the preweaning, postweaning, and overall periods $(p>0.11)$.

\subsection{Fecal Scores and Medication Usage}

Calves from dams fed low DCAD prior to calving had higher mean fecal scores before weaning and over the length of the entire experiment ( $p<0.05$; Table 7). Similarly, calves from low DCAD dams suffered from diarrhea for longer, as indicated by the increased number of days with AFS $(\geq 2 ; p<0.01)$. The number of days calves needed to be medicated also increased as a result of feeding a low DCAD $(p=0.04)$. The prepartum Ca restriction of cows (high Ca vs. low Ca) had no impact on the fecal scores or the number of days calves needed to be medicated.

Table 7. Fecal scores and number of medication days of calves from Holstein dams fed low or high Ca or a negative dietary cation-anion difference (DCAD) for 21 days before calving $(n=12)$.

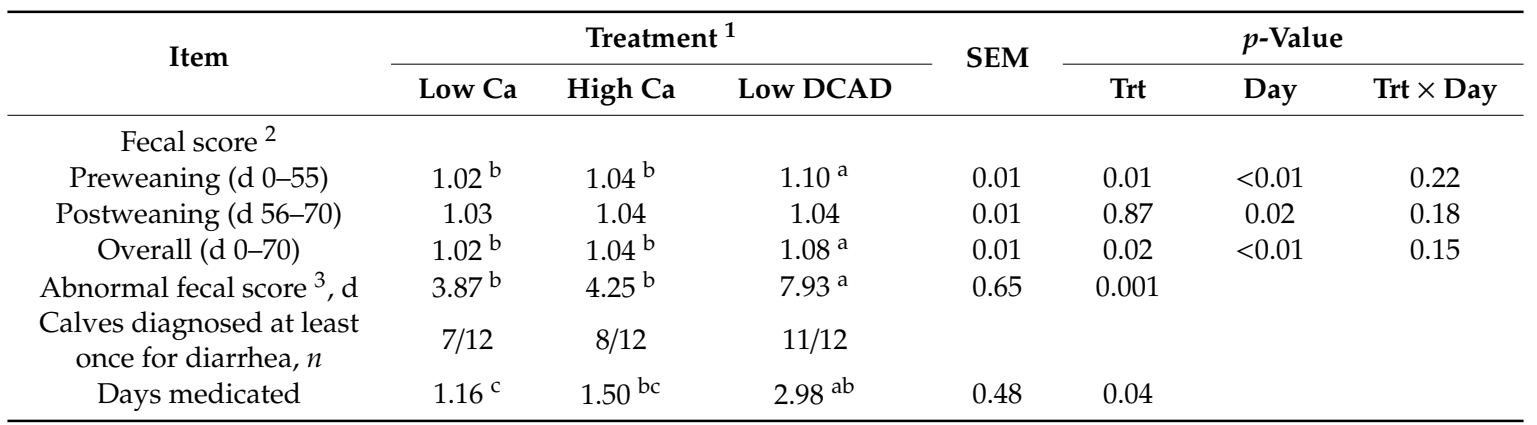

${ }^{1}$ Calves born to cows fed low Ca diet $(0.24 \% \mathrm{Ca},+86 \mathrm{mEq} / \mathrm{kghigh}$ Ca diet $(1.23 \% \mathrm{Ca},+95 \mathrm{mEq} / \mathrm{kg})$, and low DCAD (high Ca diet supplemented with SoyChlor; $1.28 \% \mathrm{Ca},-115 \mathrm{mEq} / \mathrm{kg}$; all DM basis) for $21 \mathrm{~d}$ before calving. ${ }^{2}$ Feces consistency was scored daily on a scale of $0-3,(0=$ normal consistency, $1=$ semiformed or pasty, $2=$ loose, and 3 = watery, sifts through bedding) using the Wisconsin-Madison's Calf Health Scoring chart [32]. ${ }^{3}$ Days with score $\geq 2$. ${ }^{a, b, c}$ Different superscripts indicate significant differences between the respective groups. 


\section{Discussion}

Feeding and management practices of prepartum cows affect not only the health and production performance of the dams [34] but also the quantity and composition of their colostrum, as well as the health and performance of their offspring in utero and after birth [6,14]. However, studies examining the effects of dietary changes during the close-up phase on the health and growth performance of calves in a systematic fashion are scarce. Although numerous studies reported improved Ca hemostasis, production performance, and less metabolic disorders in dairy cows in response to feeding low DCAD diets during the close-up phase, only few examined the impact of acidogenic diets fed to cows during late gestation on their colostrum and the health growth performance of their calves.

Results of this study indicate that feeding negative DCAD diets to close-up cows has no impact on the colostrum yield and composition compared to high Ca or low Ca. In agreement with our result, other studies reported that supplementation of anionic salts prepartum had no adverse effect on colostrum yield $[9,35,36]$. For example, reducing the DCAD of prepartum diets from approximately +130 to $-130 \mathrm{mEq} / \mathrm{kg}$ DM did not change colostrum quantity or its composition [36].

We did not quantify IgG, as most important colostrum quality parameter, but we are confident that the Brix value is sensitive enough to be used as proxy for colostrum quality. Brix values are highly correlated with colostrum IgG concentrations determined by a radial immunodiffusion assay [29] and Brix readings of $\geq 21 \%$ are routinely used as a threshold to screen for colostrum with high enough IgG concentration to transfer passive immunity ( $\geq 50 \mathrm{~g} \mathrm{IgG/L} \mathrm{[21]).} \mathrm{The} \mathrm{finding} \mathrm{that} \mathrm{the} \mathrm{Brix} \mathrm{value}$ and colostrum density were not affected by prepartum diets in our experiment is in agreement with several other studies, who reported that lowering the DCAD of prepartum cows did not change IgG concentration of their colostrum $[7,35,36]$.

The reason for the tendency for higher colostrum yields in response to low Ca at first milking is somewhat unclear. Higher DMI of cows receiving low Ca $(15.7 \mathrm{~kg} / \mathrm{d})$ compared to high Ca $(14.4 / \mathrm{d} \mathrm{kg})$ and low DCAD (13.7 kg/d; [23]) might have increased nutrient availability and stimulated colostrum production but colostrogenesis is complex and not only driven by nutrient supply but foremost by endocrine factors and local mechanisms within the mammary gland [37]. Diehl et al. [35] reported that prepartum Ca supply ranging from 1.8 to 1.3\% diet DM did not change the colostrum yield but affected IgG concentration and Brix value. Overall, there is only limited data concerning the impact of the dietary $\mathrm{Ca}$ level on colostrum yield and composition. This is surprising, since it is common practice to restrict the Ca intake of dairy cows before calving to reduce their risk for hypocalcemia.

We hypothesized that the reduced prepartum DMI, frequently observed in response to low DCAD diets, might negatively affect fetal growth and subsequently the calves' birth weight. Although DMI of cows offered low DCAD decreased by $2.0 \mathrm{~kg} / \mathrm{d}$ compared to low Ca [23], differences in birth weight among calves from dams fed low DCAD $(41.1 \mathrm{~kg})$ and low Ca $(43.3 \mathrm{~kg})$ were only numerical. This is in line with Weich et al. [9], who found no difference in birth weight of calves from cows fed a diet containing $-160 \mathrm{mEq} / \mathrm{kg}$ of DM (41.1 kg) compared to calves from cows fed $+120 \mathrm{mEq} / \mathrm{kg}$ DM (44.6 kg). Similarly, Diehl et al. [35] reported that feeding a diet containing - $200 \mathrm{mEq} / \mathrm{kg}$ DM for $28 \mathrm{~d}$ prepartum had no effect on the birth weight of calves compared to the control $(-30 \mathrm{mEq} / \mathrm{kg} \mathrm{DM})$.

Reduced DMI during the late stage of gestation does not always have negative consequences for the birth weight of calves. For example, restricting beef cows to $70 \%$ of their net energy requirements for the last 40 days prior to calving did not affect the weight of their calves [38]. Collazos et al. [8] reported that extending the duration of feeding acidogenic diets ( -70 and $-180 \mathrm{mEq} / \mathrm{kg} \mathrm{DM})$ from 21 to $42 \mathrm{~d}$ prepartum reduced the average birth weight of calves from 42.9 to $40.0 \mathrm{~kg}$; which is similar to the numerical difference in birth weight between calves from low Ca and low DCAD cows $(-2.2 \mathrm{~kg})$ in this study. This suggests that reduced nutrient transfer or incorporation into fetal tissues in response to feeding DCAD can occur but the extent of the reduction might depend on how far the DCAD is lowered and how long the cows are fed low DCAD diets.

The reduction in starter feed intake of calves from dams fed low DCAD, particularly during week 1 and 2, was one of the reasons for their lower BW before weaning. Based on a model developed to 
predict the growth of Holstein calves, starter intake is one of the most important factors affecting ADG and BW around weaning [39].

There are only a limited number of studies examining the effect of reduced Ca supply or low DCAD in close-up cows on the feed intake and BW development of neonatal calves. In addition, there are no studies that compare the impact of the two relatively common prepartum feeding strategies on health and growth performance of calves. In contrast to our results, Collazos et al. [8] reported that a reduction in DCAD from -70 to $-180 \mathrm{mEq} / \mathrm{kg}$ DM did not affect the BW and ADG of calves at the age of 21, 42, and 62 days, whereas extending the duration of feeding from day 21 to 42 prepartum reduced the BW of the calves at birth and day 62. It is important to note that [8] did not collect data from birth until 21 days of age, which is different compared to our study. Similar to our results, Collazos et al. [8] reported that the compromised BW of calves from dams fed low DCAD before weaning was compensated for after weaning.

Collazos et al. [8] also measured blood $\mathrm{pH}, \mathrm{pCO}_{2}$, and $\mathrm{HCO}_{3}{ }^{-}$of neonatal calves and reported that calves born to cows fed low DCAD diets $(-70$ and $-180 \mathrm{mEq} / \mathrm{kg} \mathrm{DM})$ were in a state of metabolic acidosis for three days after their birth. Extending the duration of feeding low DCAD diets from 21 to 42 days before calving exerted a more severe metabolic acidosis on the calves. However, calves from dams fed a control, non-acidogenic diet were not included in that study. Another difference is that Collazos et al. [8] fed the newborn calves with pooled colostrum, while we used colostrum of each individual dam for the first two feedings of her respective calf. This might have been a factor of influence as colostrum contains many bioactive substances that were not measured in this study but may impact the growth, morphology, and functional maturation of the gastrointestinal (GI) tract, as well as the intermediary metabolism and endocrine system of neonatal calves [40-42]. Mann et al. [43] found that changes of the energy level of prepartum diets can lead to changes in colostrum composition beyond IgG concentration, such as insulin concentration and fatty acid composition and that these compounds have an impact on the morphology of the intestinal epithelium of neonatal calves. The altered acid base balance promotes changes in vascular smooth muscle tone, which can influence circulation and blood pressure control [44]. Changes in blood flow to the mammary gland during colostrogenesis can affect the composition of colostrum [45]. In sows, lowering the dietary DCAD from 226 to $170 \mathrm{meq} / \mathrm{kg}$ during gestation increased the concentrations of serum and colostrum Ca on the first day of lactation [46]. Therefore, it is justified to speculate that the some of the findings in the present study could have been caused by differences in colostrum composition beyond the measured constituents.

Charbonneau et al. [3] reported that lowering the DCAD by about $300 \mathrm{mEq} / \mathrm{kg}$ DM induced a metabolic acidosis in prepartum dairy cows (lowered blood $\mathrm{HCO}_{3}{ }^{-}$concentration and urinary $\mathrm{pH}$ ) that was not fully compensated for. An induced short-term $(30 \mathrm{~min}$ ) acidosis (blood $\mathrm{pH}=7.06)$ in humans did not alter fetal vein $\mathrm{pH}$ but led to an efflux of total $\mathrm{CO}_{2}$ from the placenta into maternal circulation [47]. Therefore, it is possible that a metabolic acidosis of the dam induced by a negative DCAD could induce an acidosis in utero and affects postnatal BW development as the nutrient transfer system of the uterus is highly vascularized, particularly during the last trimester.

Postnatal respiratory or metabolic acidosis in calves can reduce the absorption efficiency of immunoglobulins in calves, even though they receive adequate amounts of colostrum shortly after birth [21,48]. Hypercapnia in apparently healthy newborn calves was also associated with reduced absorption of IgG from colostrum [49]. In contrast, metabolic acidosis in calves born to cows fed low DCAD diets prepartum did not change the efficiency of IgG absorption [8]. Similarly, calves from dams receiving anionic salts before calving $-100 \mathrm{mEq} / \mathrm{kg}$ DM) had similar serum IgG concentrations (15.1 vs. $14.4 \mathrm{~g} / \mathrm{L}$ ) and apparent efficiency of absorption compared to calves born from control dams [38].

Unfortunately, transfer of IgG to the calves was not measured in the current study but the serum concentration of total protein on days $0,1,7,35$, and 70 for calves from dams fed low DCAD was similar in low $\mathrm{Ca}$ and high Ca calves. Passive transfer of immunity to calves can be assessed directly by measuring serum IgG or estimated based on the total protein concentration in the serum $[50,51]$. A failure of passive transfer can be assumed if total serum protein concentrations are $<5.2 \mathrm{~g} / \mathrm{dL}$ [52]. 
A total serum protein concentration of calves in this study was $6.42 \pm 0.42 \mathrm{~g} / \mathrm{dL}$ at day 1 and was similar among treatments. Therefore, it can be assumed that the lower preweaning BW and reduced growth performance of calves from dams fed DACD was not caused by insufficient IgG transfer and a lack of passive immunity.

Calves in this study were generally healthy and we had no mortalities. Only one calf (high Ca group) suffered from a respiratory infection. However, calves born to cows fed low DCAD had higher fecal scores, increased number of days with AFS $(\geq 2)$, and they required medication more frequently, especially during week 1 and 2. Similar to low Ca (3.87) and high Ca calves (4.25) in this study, Bateman et al. [39] reported that an AFS of 4.7 days was common for neonate Holstein calves. In contrast, calves born to dams fed low DCAD in this study experienced 7.93 days with AFS. Unsurprisingly, growth performance of calves is negatively affected by an increase in the number of days with diarrhea [39]. When calves are sick, energy is needed for the immune response and less energy is partitioned towards growth [53]. Furthermore, inflammation of the GI tract and increase in digesta passage in response to diarrhea commonly lead to a reduction of nutrient absorption [54]. Similarly, to reduced growth performance, occurrence of diarrhea in dairy calves can have negative impact on first lactation performance and be associated with reduced milk yield [55].

In contrast to our results, feeding a negative DCAD ( -70 and $-180 \mathrm{mEq} / \mathrm{kg} \mathrm{DM})$ to close-up cows in a previous study did not change the percentage of young calves that had to be treated for diarrhea [8]. However, the apparent discrepancy between Collazos et al. [8] and our study should to be interpreted carefully. We scored the feces of the calves daily between day 1 and 70, whereas Collazos et al. [8] only recorded fecal scores on day 21 and 42. Typically, calves suffer from diarrhea during the first 28 days of life, while the most common period is the first 21 days [56].

Although $\mathrm{Ca}, \mathrm{Mg}$, and $\mathrm{P}$ concentrations in the serum of the calves were not affected by the dietary treatment of the dams, serum $\mathrm{K}$ concentration on day 1 and 7 increased in calves born to low DCAD dams. This could be indicative of compensation of metabolic acidosis as well as an inflammation of the GI tract and loss of buffer through feces. Hyperkalemia is a common electrolyte disturbance in diarrheic calves [57-59] and blood $\mathrm{pH}$, base excess, and $\mathrm{HCO}_{3}{ }^{-}$were lower, whereas serum $\mathrm{K}$ and $\mathrm{Na}$ were elevated in diarrheic calves compared to clinical healthy calves [60]. Trefz et al. [61] reported that serum potassium concentrations $>5.8 \mathrm{mmol} / \mathrm{L}$ were more closely associated with dehydration and diarrhea than with decreases in base excess or venous blood $\mathrm{pH}$.

Unfortunately, we did not measure the acid-base balance or blood $\mathrm{pH}$ of the calves in our study. Therefore, conclusions in this regard are largely speculative. However, the mean urine $\mathrm{pH}$ of cows fed low DCAD ( $\mathrm{pH} 5.6)$ was lower than commonly observed ( $\mathrm{pH} 6-7 ;[3,62])$ and also lower compared to cows fed low $\mathrm{Ca}(\mathrm{pH} 7.81)$ and high $\mathrm{Ca}$ ( $\mathrm{pH}$ 8.14). This would indicate a challenge of the acid-base balance of low DCAD dams, which might have also affected the fetuses. The average urine $\mathrm{pH}$ of cows fed low DCAD in the current experiment was similar to the urine $\mathrm{pH}$ reported by Collazos et al. [8] in response to feeding $-180 \mathrm{mEq} / \mathrm{kg}$ diet DM. Calves born to cows fed the ration containing $-180 \mathrm{mEq} / \mathrm{kg}$ DM experienced metabolic acidosis for three days after birth [8]. This supports the assumption that calves from dams fed low DCAD in the current study may have been in a state of metabolic acidosis, which might have affected their health, increased the likelihood of developing diarrhea, and impacted their growth performance until weaning. Further research would be required to evaluate the long-term effect of this on the performance of heifers during first lactation, as for every $100 \mathrm{~g}$ decrease in BW before weaning; first lactation milk yield can be expected to decrease by $155 \mathrm{~kg}$ [63].

\section{Conclusions}

Feeding low DCAD or Ca restricted during the close-up phase did not change the colostrum quantity or composition, while cows fed low Ca tended to produce more colostrum compared to dams fed high Ca before calving. Feeding low DCAD to prepartum cows increased the likelihood of diarrhea and serum K concentrations of their calves before weaning. Calves born to dams fed low DCAD during close-up also had lower BW and ADG during the first two weeks and tended to have lower BW before 
weaning compared calves from cows fed high Ca and low Ca. The delay in the growth development observed in calves born to dams fed low DCAD was compensated after weaning ( $\mathrm{d}$ 55-70).

Author Contributions: Conceptualization, G.R.G. and A.R.; methodology, A.R.; software, A.S.-S.; validation, A.S.-S., M.K. and G.R.G.; formal analysis, A.S. and A.H.M.; investigation, A.R. and S.R.; writing-original draft preparation, A.R.; writing-review and editing, M.R.W. and M.H.; supervision, G.R.G., M.R.W. and M.H.; project administration, A.R.; funding acquisition, G.R.G. All authors have read and agreed to the published version of the manuscript.

Funding: This study was supported by Isfahan University of technology (IUT), Animal Science Group, project ID; IRN-0002-5-20.

Acknowledgments: The authors would like to thank the staff of the Lavark Research Station of IUT. We appreciate the assistance of Mohammad Reza Zakaria, Mina Mohammadi, Narges Arpanahi, and ZahraRahimi Zaman Abadi (all IUT students) in handling calves and collecting data. In addition, we would like to thank Amir Mansour Vatankhah (Drug Applied Research Center, Tabriz University of Medical Science; Tabriz, Iran) for analyses of the blood samples and Farzad Hashemzadeh (IUT) for assistance with the statistical analysis.

Conflicts of Interest: The authors declare no conflict of interest.

\section{References}

1. Lean, I.J.; Santos, J.E.P.; Block, E.; Golder, H.M. Effects of prepartum dietary cation-anion difference intake on production and health of dairy cows: A meta-analysis. J. Dairy Sci. 2019, 102, 2103-2133. [CrossRef]

2. Santos, J.E.P.; Lean, I.J.; Golder, H.; Block, E. Meta-analysis of the effects of prepartum dietary cation-anion difference on performance and health of dairy cows. J. Dairy Sci. 2019, 102, 2134-2154. [CrossRef] [PubMed]

3. Charbonneau, E.; Pellerin, D.; Oetzel, G.R. Impact of Lowering Dietary Cation-Anion Difference in Nonlactating Dairy Cows: A Meta-Analysis. J. Dairy Sci. 2006, 89, 537-548. [CrossRef]

4. Schoonmaker, J.; Eastridge, M. Effect of maternal nutrition on calf health and growth. In Proceedings of the 22nd Tri-State Dairy Nutrition Conference, Fort Wayne, IN, USA, 23-24 April 2013; pp. 63-80.

5. Wu, G.; Bazer, F.W.; Wallace, J.M.; Spencer, T.E. BOARD-INVITED REVIEW: Intrauterine growth retardation: Implications for the animal sciences1. J. Ani. Sci. 2006, 84, 2316-2337. [CrossRef] [PubMed]

6. Du, M.; Tong, J.; Zhao, J.; Underwood, K.R.; Zhu, M.; Ford, S.P.; Nathanielsz, P.W. Fetal programming of skeletal muscle development in ruminant animals1. J. Ani. Sci. 2010, 88, E51-E60. [CrossRef] [PubMed]

7. Lopera, C.; Zimpel, R.; Vieira-Neto, A.; Lopes, F.R.; Ortiz, W.; Poindexter, M.; Faria, B.N.; Gambarini, M.L.; Block, E.; Nelson, C.D.; et al. Effects of level of dietary cation-anion difference and duration of prepartum feeding on performance and metabolism of dairy cows. J. Dairy Sci. 2018, 101, 7907-7929. [CrossRef]

8. Collazos, C.; Lopera, C.; Santos, J.E.P.; Laporta, J. Effects of the level and duration of maternal diets with negative dietary cation-anion differences prepartum on calf growth, immunity, and mineral and energy metabolism. J. Dairy Sci. 2017, 100, 9835-9850. [CrossRef]

9. Weich, W.; Block, E.; Litherland, N.B. Extended negative dietary cation-anion difference feeding does not negatively affect postpartum performance of multiparous dairy cows. J. Dairy Sci. 2013, 96, 5780-5792. [CrossRef]

10. Planski, B.; Abrashev, N. Dynamic aspects of mineral metabolism in dry cows, puerperants and calves. Vet. Med. Nauki 1987, 24, 48-57.

11. Wilhelm, A.L.; Maquivar, M.G.; Bas, S.; Brick, T.A.; Weiss, W.P.; Bothe, H.; Velez, J.S.; Schuenemann, G.M. Effect of serum calcium status at calving on survival, health, and performance of postpartum Holstein cows and calves under certified organic management. J. Dairy Sci. 2017, 100, 3059-3067. [CrossRef]

12. Vagnoni, D.B.; Oetzel, G.R. Effects of Dietary Cation-Anion Difference on the Acid-Base Status of Dry Cows. J. Dairy Sci. 1998, 81, 1643-1652. [CrossRef]

13. Omo-Aghoja, L. Maternal and fetal Acid-base chemistry: A major determinant of perinatal outcome. Ann. Med. Health. Sci. Res. 2014, 4, 8-17. [CrossRef] [PubMed]

14. Abuelo, A. Symposium review: Late-gestation maternal factors affecting the health and development of dairy calves. J. Dairy Sci. 2020, 103, 3882-3893. [CrossRef] [PubMed]

15. Massip, A. The Relation Between the Type of Delivery and the Acid-Base and Plasma Cortisol Levels of the Newborn Calf. Br. Vet. J. 1980, 136, 488-491. [CrossRef]

16. Szenci, O. Role of acid-base disturbances in perinatal mortality of calves. Acta Vet. Hung. 1985, 33, $205-220$. 
17. Lombard, J.E.; Garry, F.B.; Tomlinson, S.M.; Garber, L.P. Impacts of Dystocia on Health and Survival of Dairy Calves. J. Dairy Sci. 2007, 90, 1751-1760. [CrossRef]

18. Roshanzamir, H.; Rezaei, J.; Fazaeli, H. Colostrum and milk performance, and blood immunity indices and minerals of Holstein cows receiving organic $\mathrm{Mn}, \mathrm{Zn}$ and $\mathrm{Cu}$ sources. Anim. Nutr. 2020, 6, 61-68. [CrossRef]

19. Joyce, P.W.; Sanchez, W.K.; Goff, J.P. Effect of Anionic Salts in Prepartum Diets Based on Alfalfa1. J. Dairy Sci. 1997, 80, 2866-2875. [CrossRef]

20. Guy, M.; Sanchez, W.; Higgins, J.; Crill, R.; Giesy, J. Effect of an oral paste of sodium bicarbonate given at parturition on immunoglobulin status of neonatal calves. J. Dairy Sci. 1996, 79, 198.

21. Quigley, J.D.; Drewry, J.J. Nutrient and Immunity Transfer from Cow to Calf Pre- and Postcalving. J. Dairy Sci. 1998, 81, 2779-2790. [CrossRef]

22. Joyce, P.W.; Sanchez, W.K. Dietary cation-anion difference and forage type during the dry period: Effect on lactational Joyce, performance and metabolic disorders of cows and health of calves. J. Dairy Sci. 1994, 77, 97.

23. Rajaeerad, A.; Ghorbani, G.R.; Khorvash, M.; Sadeghi-Sefidmasgi, A.; Mahdavi, A.H.; Wilkens, M.R. Comparison of prepartum diets varying in dietary cation anion difference and $\mathrm{K}$ and $\mathrm{Ca}$ contents for prevention of hypocalcemia. In Advances in Animal Biosciences, Proceedings of the XIIth International Symposium on Ruminant Physiology, Leipzig, Germany, 3-6 September 2019; Cambridge University Press: Cambridge, UK, 2019; Volume 10, p. 435.

24. Rajaeerad, A.; Ghorbani, G.R.; Khorvash, M.; Sadeghi-Sefidmasgi, A.; Mahdavi, A.H.; Boroumand-Jazi, M.; Wilkens, M.R. Comparison of prepartum diets varying in dietary cation anion difference and $\mathrm{K}$ and $\mathrm{Ca}$ contents for prevention of hypocalcemia. J. Anim. Physiol. Anim. Nutr. 2020. submitted for publication.

25. Fox, D.; Tylutki, T.; Czymmek, K.; Rasmussen, C.; Durbal, V. Development and application of the Cornell University nutrient management planning system. In Proceedings of the 2000 Cornell nutrient Conference for Feed Manufacturers, Rochester, NY, USA, 24-26 October 2000; Cornell University: Ithaca, NY, USA, 2000; pp. 167-179.

26. Council, N.R. Nutrient Requirements of Dairy Cattle: 2001; National Academies Press: Washington, DC, USA, 2001.

27. Schuenemann, G.M.; Nieto, I.; Bas, S.; Galvão, K.N.; Workman, J. Assessment of calving progress and reference times for obstetric intervention during dystocia in Holstein dairy cows. J. Dairy Sci. 2011, 94, 5494-5501. [CrossRef]

28. Fleenor, W.A.; Stott, G.H. Hydrometer Test for Estimation of Immunoglobulin Concentration in Bovine Colostrum1. J. Dairy Sci. 1980, 63, 973-977. [CrossRef]

29. Bielmann, V.; Gillan, J.; Perkins, N.R.; Skidmore, A.L.; Godden, S.; Leslie, K.E. An evaluation of Brix refractometry instruments for measurement of colostrum quality in dairy cattle. J. Dairy Sci. 2010, 93, 3713-3721. [CrossRef]

30. Association of Official Analytical Chemists (AOAC). Official methods of analysis: Changes in Official Methods of Analysis Made at the Annual Meeting. Supplement; Association of Official Analytical Chemists: Washington, DC, USA, 1990; Volume 15.

31. Van Soest, P.J.; Robertson, J.B.; Lewis, B.A. Methods for Dietary Fiber, Neutral Detergent Fiber, and Nonstarch Polysaccharides in Relation to Animal Nutrition. J. Dairy Sci. 1991, 74, 3583-3597. [CrossRef]

32. McGuirk, S.M. Disease Management of Dairy Calves and Heifers. Vet. Clin. North. Am. Food. Anim. Pract. 2008, 24, 139-153. [CrossRef] [PubMed]

33. Littell, R.C.; Milliken, G.; Stroup, W.W.; Wolfinger, R.; Schabenberger, O. SAS for Mixed Models; Taylor \& Francis: Abingdon, UK, 2007; Volume 61.

34. Overton, T.R.; Waldron, M.R. Nutritional Management of Transition Dairy Cows: Strategies to Optimize Metabolic Health. J. Dairy Sci. 2004, 87, E105-E119. [CrossRef]

35. Diehl, A.L.; Bernard, J.K.; Tao, S.; Smith, T.N.; Marins, T.; Kirk, D.J.; McLean, D.J.; Chapman, J.D. Short communication: Blood mineral and gas concentrations of calves born to cows fed prepartum diets differing in dietary cation-anion difference and calcium concentration. J. Dairy Sci. 2018, 101, 9048-9051. [CrossRef] [PubMed]

36. Martinez, N.; Rodney, R.M.; Block, E.; Hernandez, L.L.; Nelson, C.D.; Lean, I.J.; Santos, J.E.P. Effects of prepartum dietary cation-anion difference and source of vitamin $\mathrm{D}$ in dairy cows: Lactation performance and energy metabolism. J. Dairy Sci. 2018, 101, 2544-2562. [CrossRef] 
37. Barrington, G.M.; McFadden, T.B.; Huyler, M.T.; Besser, T.E. Regulation of colostrogenesis in cattle. Livest. Prod. Sci. 2001, 70, 95-104. [CrossRef]

38. Moriel, P.; Piccolo, M.B.; Artioli, L.F.; Marques, R.S.; Poore, M.H.; Cooke, R.F. Short-term energy restriction during late gestation of beef cows decreases postweaning calf humoral immune response to vaccination. $J$. Anim. Sci. 2016, 94, 2542-2552. [CrossRef] [PubMed]

39. Bateman, H.G.; Hill, T.M.; Aldrich, J.M.; Schlotterbeck, R.L.; Firkins, J.L. Meta-analysis of the effect of initial serum protein concentration and empirical prediction model for growth of neonatal Holstein calves through 8 weeks of age. J. Dairy Sci. 2012, 95, 363-369. [CrossRef] [PubMed]

40. Blättler, U.; Hammon, H.M.; Morel, C.; Philipona, C.; Rauprich, A.; Romé, V.; Le Huërou-Luron, I.; Guilloteau, P.; Blum, J.W. Feeding Colostrum, Its Composition and Feeding Duration Variably Modify Proliferation and Morphology of the Intestine and Digestive Enzyme Activities of Neonatal Calves. J. Nutr. 2001, 131, 1256-1263. [CrossRef] [PubMed]

41. Blum, J.W. Nutritional physiology of neonatal calves. J. Anim. Physiol. Anim. Nutr. 2006, 90, 1-11. [CrossRef]

42. Ontsouka, E.C.; Albrecht, C.; Bruckmaier, R.M. Invited review: Growth-promoting effects of colostrum in calves based on interaction with intestinal cell surface receptors and receptor-like transporters. J. Dairy Sci. 2016, 99, 4111-4123. [CrossRef]

43. Mann, S.; Leal Yepes, F.A.; Overton, T.R.; Lock, A.L.; Lamb, S.V.; Wakshlag, J.J.; Nydam, D.V. Effect of dry period dietary energy level in dairy cattle on volume, concentrations of immunoglobulin $\mathrm{G}$, insulin, and fatty acid composition of colostrum. J. Dairy Sci. 2016, 99, 1515-1526. [CrossRef]

44. Celotto, A.C.; Capellini, V.K.; Baldo, C.F.; Dalio, M.B.; Rodrigues, A.J.; Evora, P.R.B. Effects of acid-base imbalance on vascular reactivity. Braz. J. Med. Biol. Res. 2008, 41, 439-445. [CrossRef]

45. Aragona, K.M.; Chapman, C.E.; Pereira, A.B.D.; Isenberg, B.J.; Standish, R.B.; Maugeri, C.J.; Cabral, R.G.; Erickson, P.S. Prepartum supplementation of nicotinic acid: Effects on health of the dam, colostrum quality, and acquisition of immunity in the calf. J. Dairy Sci. 2016, 99, 3529-3538. [CrossRef] [PubMed]

46. Guo, J.Y.; Pasquetti, T.J.; Kim, S.W. Lowering dietary cation-anion difference increases sow blood and milk calcium concentrations. J. Ani. Sci. 2019, 97, 2927-2939. [CrossRef]

47. Aarnoudse, J.G.; Illsley, N.P.; Penfold, P.; Bardsley, S.E.; Rispens, P.; Hytten, F.E. Permeability of the human placenta to bicarbonate: In-vitro perfusion studies. Br. J. Obstet. Gynaecol. 1984, 91, 1096-1102. [CrossRef]

48. Besser, T.E.; Szenci, O.; Gay, C.C. Decreased colostral immunoglobulin absorption in calves with postnatal respiratory acidosis. J. Am. Vet. Med. Assoc. 1990, 196, 1239-1243. [PubMed]

49. Boyd, J.W. Relationships between acid-base balance, serum composition and colostrum absorption in newborn calves. Br. Vet. J. 1989, 145, 249-256. [CrossRef]

50. U.S. Department of Agriculture (USDA); Animal and Plant Health Inspection Service (APHIS); Veterinary Services (VS); National Animal Health Monitoring System (NAHMS). Dairy 2007: Heifer Calf Health and Management Practices on U.S. Dairy Operations, 2007; USDA: Fort Collins, CO, USA, 2010.

51. Wallace, M.M.; Jarvie, B.D.; Perkins, N.R.; Leslie, K.E. A comparison of serum harvesting methods and type of refractometer for determining total solids to estimate failure of passive transfer in calves. Can. Vet. J. 2006, 47, 573-575. [PubMed]

52. Calloway, C.D.; Tyler, J.W.; Tessman, R.K.; Hostetler, D.; Holle, J. Comparison of refractometers and test endpoints in the measurement of serum protein concentration to assess passive transfer status in calves. $J$. Am. Vet. Med. Assoc. 2002, 221, 1605-1608. [CrossRef] [PubMed]

53. Constable, P.D. Treatment of Calf Diarrhea: Antimicrobial and Ancillary Treatments. Vet. Clin. North Am. Food. Anim. Pract. 2009, 25, 101-120. [CrossRef]

54. Klein, P.; Kleinová, T.; Volek, Z.; Simůnek, J. Effect of Cryptosporidium parvum infection on the absorptive capacity and paracellular permeability of the small intestine in neonatal calves. Vet. Parasitol. 2008, 152, 53-59. [CrossRef] [PubMed]

55. Gelsinger, S.L.; Heinrichs, A.J.; Jones, C.M. A meta-analysis of the effects of preweaned calf nutrition and growth on first-lactation performance1. J. Dairy Sci. 2016, 99, 6206-6214. [CrossRef] [PubMed]

56. Cho, Y.I.; Yoon, K.J. An overview of calf diarrhea - infectious etiology, diagnosis, and intervention. J. Vet. Sci. 2014, 15, 1-17. [CrossRef]

57. Groutides, C.; Michell, A.R. Evaluation of acid-base disturbances in calf diarrhoea. Ve.t Rec. 1990, 126, $29-31$. [CrossRef] [PubMed] 
58. Seifi, H.A.; Mohri, M.; Shoorei, E.; Farzaneh, N. Using haematological and serum biochemical findings as prognostic indicators in calf diarrhoea. Comp. Clin. Path. 2006, 15, 143-147. [CrossRef]

59. Koch, A.; Kaske, M. Clinical efficacy of intravenous hypertonic saline solution or hypertonic bicarbonate solution in the treatment of inappetent calves with neonatal diarrhea. J. Vet. Intern. Med. 2008, 22, 202-211. [CrossRef] [PubMed]

60. Sobiech, P.; Rekawek, W.; Ali, M.; Targoński, R.; Zarczyńska, K.; Snarska, A.; Stopyra, A. Changes in blood acid-base balance parameters and coagulation profile during diarrhea in calves. Pol. J. Vet. Sci. 2013, 16, 543-549. [CrossRef]

61. Trefz, F.M.; Constable, P.D.; Sauter-Louis, C.; Lorch, A.; Knubben-Schweizer, G.; Lorenz, I. Hyperkalemia in neonatal diarrheic calves depends on the degree of dehydration and the cause of the metabolic acidosis but does not require the presence of acidemia. J. Dairy Sci. 2013, 96, 7234-7244. [CrossRef] [PubMed]

62. Goff, J.P. The monitoring, prevention, and treatment of milk fever and subclinical hypocalcemia in dairy cows. Vet. J. 2008, 176, 50-57. [CrossRef] [PubMed]

63. Soberon, F.; Van Amburgh, M.E. LACTATION BIOLOGY SYMPOSIUM: The effect of nutrient intake from milk or milk replacer of preweaned dairy calves on lactation milk yield as adults: A meta-analysis of current data1. J. Ani. Sci. 2013, 91, 706-712. [CrossRef]

(C) 2020 by the authors. Licensee MDPI, Basel, Switzerland. This article is an open access article distributed under the terms and conditions of the Creative Commons Attribution (CC BY) license (http://creativecommons.org/licenses/by/4.0/). 